\title{
Age structure of Levant water frog, Pelophylax bedriagae, in Lake Sülüklü (Western Anatolia, Turkey)
}

\author{
Kerim Çiçek*, Meltem Kumaş, Dinçer Ayaz, Ahmet Mermer, Ş. Deniz Engin \\ Ege University, Faculty of Science, Biology Department, Zoology Section, Bornova-Izmir, Turkey \\ ${ }^{*}$ Correspondence: Ege University, Faculty of Science, Biology Department, Zoology Section, 35100, Bornova-Izmir, Turkey. Phone: \\ +90 (232) 3112409, Fax: +90 (232) 3881036. E-mail: kerim.cicek@ege.edu.tr, kerim.cicek@hotmail.com
}

Received: 8 June 2011; received in revised form: 23 September 2011; accepted: 23 September 2011.

During the present study, we obtained data via skeletochronology on the age structure of Levant water frog, Pelophylax bedriagae, in Lake Sülüklü (Manisa, Turkey). The mean snout-vent length was $56.1 \mathrm{~mm}$ (SD = 7.7) for males and $64.5 \mathrm{~mm}(\mathrm{SD}=14.8)$ for females. While both sexes reached sexual maturity following their second hibernation, the modal age was two years for males and three years for females. The average age of the adult population was 2.50 years $(S D=0.65$, range $=2-4)$ in males and 2.95 years $(S D=0.99$, range $=2-5)$ in females. Furthermore, the threatening factors of Lake Sülüklü population were outlined.

Key words: ; Pelophylax bedriagae; skeletochronology; Turkey; Western Anatolia.

Estructura de edad de la rana verde levantina, Pelophylax bedriagae, en el lago Sülüklü (Anatolia occidental, Turquía). Durante el presente estudio obtuvimos datos, mediante un análisis esqueletocronológico, sobre la estructura de edades de la rana verde levantina, Pelophylax bedriagae, en el lago Sülüklü (Manisa, Turquía). La longitud media hocico-cloaca fue de 56,1 mm (SD = 7,7) en machos y 64,5 mm (SD = 14,8) en hembras. Mientras que en ambos sexos la madurez sexual se alcanzó tras la segunda hibernación, la edad modal fue dos años para los machos y tres años para las hembras. La edad media en la población adulta fue 2,50 años $(\mathrm{SD}=0,65$, rango $=2-4)$ en los machos y 2,95 años $(\mathrm{SD}=0,99$, rango $=2-5$ ) en las hembras. Por último, se indicaron algunas de las amenazas que afectan a la población estudiada.

Key words: occidental; edad; esqueletocronología; Pelophylax bedriagae; Turquía.

Palearctic water frogs of the genus Pelophylax Fitzinger, 1843 contain 22 taxa and are widely distributed in Eurasia (Beerli, 1995; Frost, 2011). The Levant water frog, Pelophylax bedriagae, is distributed across the eastern Mediterranean (PAPENFUss et al., 2008; Frost, 2011). In Turkey, the species is widespread along the western and southern parts of Anatolia (PAPENFUSS et al., 2008).

Pelophylax bedriagae is threatened by habitat loss as a consequence of wetland drainage, pollution, drought and urbanization of coastal areas (PAPENFUSs et al., 2008; AMPHIBIAWEB, 2011). It is also threatened by collection for human consumption, being the individuals collected from Turkey exported to western Europe (BARAN et al., 1992; PAPENFUss et al., 2008). Its populations tend to decrease, in spite of which the species is included in the category of 'Least Concern' in the Red List of the International Union for Conservation of Nature (PAPENFUSS et al., 2008).

Determining the age structure of populations is essential in understanding the population dynamics and breeding of species. Regarding amphibians and reptiles, skeletochronology is a widely used method for age estimation (CASTANET \& SMIRINA, 1990; 
CASTANET et al., 1993; SMIRINA, 1994). Skeletochronology is based on the observation of annual growth rings found in bones; these rings are formed during the hibernation phases, and are commonly known as lines of arrested growth (LAGs) (CASTANET et al., 1977). In many amphibians and reptiles, skeletochronology is a non-destructive technique as it can be performed on the phalanges, without sacrificing the individuals (SMIRINA, 1972; Hemelaar, 1985; Castanet \& SMIRINA, 1990). The aim of the present study was to assess, through the skeletochronological study of phalanges, the age structure of P. bedriagae population inhabiting Lake Sülüklü in order to retrieve information about growth, size at maturity and longevity.

\section{MATERIALS AND METHODS}

The study site, Lake Sülüklü, is located on the northeastern slope of Mount Spil $\left(38.565035^{\circ} \mathrm{N}, 27.532617^{\circ} \mathrm{E}, 612 \mathrm{~m}\right.$ above seal level), in Manisa (Western Anatolia, Turkey). The surface area of the lake is nearly 1.58 ha and its depth $2-4 \mathrm{~m}$. Three amphibian species other than $P$. bedriagae inhabit the lake: Pseudopidalea viridis, Lissotriton vulgaris and Triturus karelinii.

A total of 40 individuals (four juveniles, 14 males, and 22 females) were captured on May 4th 2010, at the end of the breeding season, from Lake Sülüklü. The sex of all individuals was determined through the observation of vocal sacs and nuptial pads present in males, and their snout-vent lengths (SVL) were measured to the nearest $0.1 \mathrm{~mm}$ using digital calipers. The second phalange of the fourth toe of the right hind limb was sectioned and stored in 70\% alcohol. Then, the individuals were released in the same place they were captured.

The bones were fixed in 10\% buffered formalin for 24 hours and then left in tap water for 24 hours. Decalcification was performed with 5\% nitric acid for 2-4 hours according to the size of the bone, after which bones were kept in tap water for another 24 hours in order to wash the acid. Tissue samples were embedded in paraffin and 15-micron thin transversal sections were obtained from the middle of the diaphysis. The sections were stained by immersion in Ehrlich's hematoxylin for 20 minutes. LAGs were counted by two observers who were blind to the identification of the individuals. All mount preparations were photographed with an Olympus LC20 Soft Imaging System (Olympus, Münster, Germany) and observed with a light microscope. For each phalange, we selected at least three cross sections from the mid-diaphyseal level, the area of the bone with the smallest marrow cavity. The diameters of medullary cavity (MC), metamorphosis line (ML), resorption line (RL), each visible LAG, and periosteal outer margin were measured in each individual in order to estimate endosteal resorption. When diameter of innermost visible LAG was > 2 standard deviations greater than its group mean, the first LAG was considered as eroded, being the innermost visible LAG actually the second one (e.g. TSiora \& KyriakoupolouSKLAVOUNOU, 2002; GUARINO et al., 2008).

The age of maturity was identified using the first decreasing interval between LAGs, which is supposed to indicate the attainment of sexual maturity as proposed by KLEINENBERG \& SMIRINA (1969) and widely used by many authors (e.g. SMIRINA, 1994; 
TSIORA \& KYRIAKOPOULOU-SKLAVOUNOU, 2002; YILMAZ et al., 2005; GUARINO et al., 2008; GÜl et al., 2011). Besides, the sexual maturity was confirmed when possible through the observation of the sexual secondary characters mentioned above. Longevity was determined as the age of the oldest individual of each sex in the population.

SVL and age structure were compared between sexes with a t-test and a Mann Whitney's U-test, respectively. Growth was estimated by the equation of von BERTALANFFY (1983), which has been previously used in several studies on amphibians (ARNTZEN, 2000; Miaud et al., 2001; CoĞalniceanu \& Miaud, 2003, SarasolaPUENTE et al., 2011). The growth formula was applied as used by HEMELAAR (1988):

$$
S V L_{t}=S V L_{\text {max }}-\left(S V L_{\text {max }}-S V L_{\text {met }}\right) e^{-K\left(t-t_{\text {met }}\right)}
$$

where $S V L_{t}$ is the average length at age t, $S V L_{\text {max }}$ the average maximum length, $S V L_{\text {met }}$ the average length at metamorphosis, $t$ the number of growing season experienced (age), $t_{\text {met }}$ the intercept with time axis (time of metamorphosis), and $\mathrm{K}$ the growth rate coefficient. Units are given in growth increase per year. $S V L_{\text {max }}, K, t_{\text {met }}$ and their standard errors were estimated through the nonlinear leastsquare regression with $\mathrm{R}$ version 2.12.2 ( $\mathrm{R}$ Development Core Team, 2011). The alpha level was set to 0.05 .

\section{RESULTS}

The mean SVL was $42.4 \mathrm{~mm}(\mathrm{SD}=7.76$; $\mathrm{N}=4)$ in juveniles, $56.1 \mathrm{~mm}(\mathrm{SD}=7.68$; $\mathrm{N}=14)$ in males and $64.5 \mathrm{~mm}(\mathrm{SD}=4.61$; $\mathrm{N}=22$ ) in females (Table 1). The females were larger than the males $\left(\mathrm{t}_{34}=2.25 ; P=0.031\right)$. LAGs were seen in all phalangeal sections and their sharpness was different. They were very clear in 29 out of the 40 studied individuals (Fig. 1a), barely perceptible in another nine, and different in thickness in the remaining two specimens (Fig. 1b). Furthermore, double resting lines (DL) were observed in three individuals (Fig. 1c). The first LAG was entirely resorbed by the endosteal bone in 16 individuals (one juvenile, seven males and eight females) and partially resorbed by the endosteal bone in the rest of the examined individuals.

The average age was 2.50 years $(\mathrm{SD}=0.65$; range $2-4)$ in males and 2.95 years $(S D=0.99$;

Table 1: Snout-vent length mean values and ranges related to each sex and age, as estimated by skeletochronology, in Pelophylax bedriagae from Lake Sülüklü.

\begin{tabular}{cccccccccc}
\hline \hline \multirow{2}{*}{ Age (years) } & \multicolumn{4}{c}{ Juveniles } & \multicolumn{2}{c}{ Males } & \multicolumn{2}{c}{ Females } \\
& $\mathrm{N}$ & Mean (SD) & Range & $\mathrm{N}$ & Mean (SD) & Range & $\mathrm{N}$ & Mean (SD) & Range \\
\hline 1 & 3 & $38.6(1.3)$ & $37.0-39.3$ & & & & & & \\
2 & 1 & 53.9 & & 8 & $52.6(3.2)$ & $50.4-60.0$ & 8 & $59.8(11.4)$ & $45.8-83.1$ \\
3 & & & & 5 & $58.2(8.4)$ & $50.7-72.2$ & 10 & $64.0(14.3)$ & $52.2-86.2$ \\
4 & & & & 1 & 73.2 & & 1 & 64.2 & \\
5 & & & & & & & 3 & $78.6(22.0)$ & $53.2-92.4$ \\
Total & 4 & $42.4(7.8)$ & $37.0-53.9$ & 14 & $56.1(7.7)$ & $50.4-73.2$ & 22 & $64.5(14.6)$ & $45.8-92.4$ \\
\hline
\end{tabular}




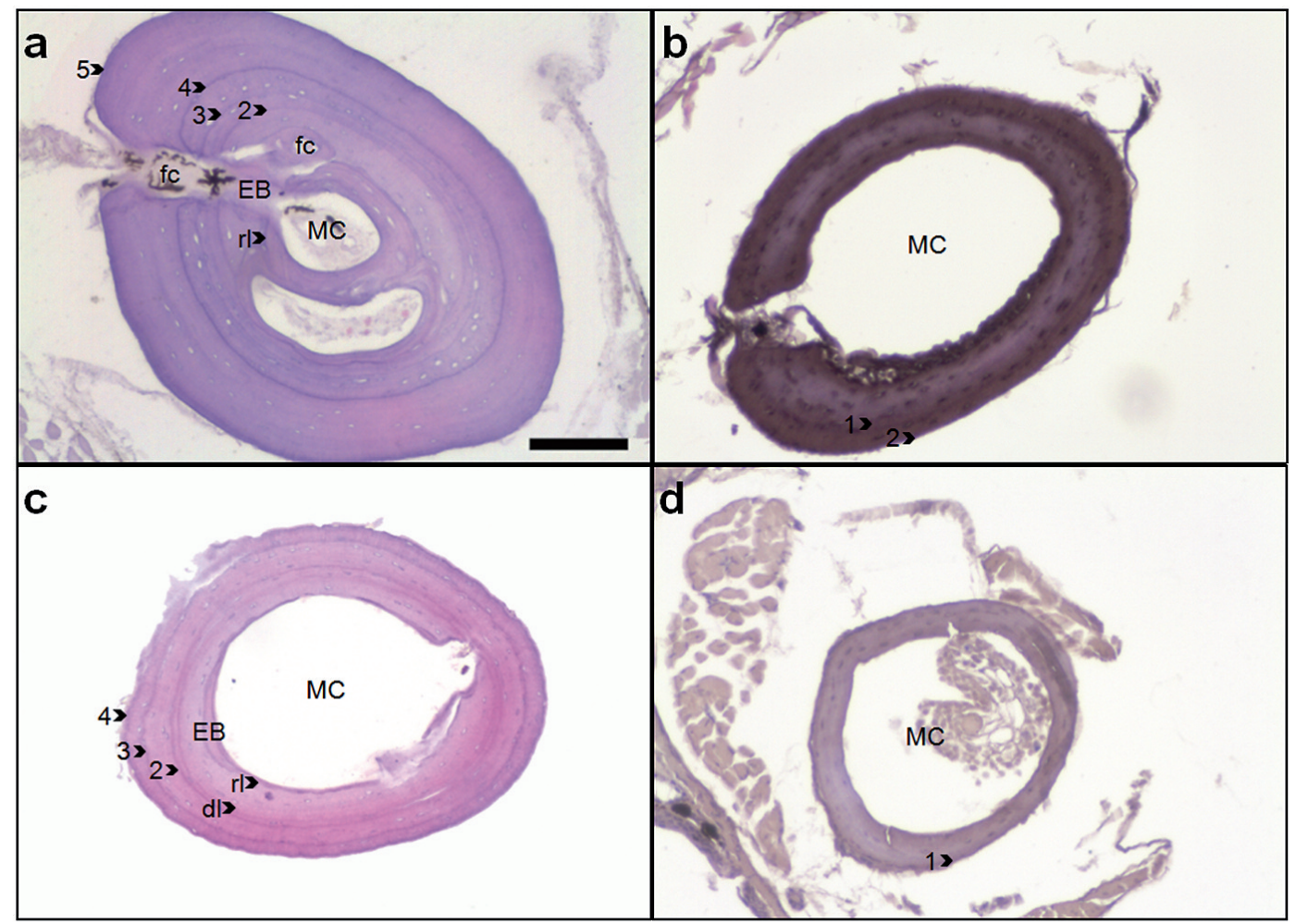

Figure 1: Phalangeal cross-sections of Pelophylax bedriagae from Lake Sülüklü (Western Anatolia). (a) five year-old male $(73.5 \mathrm{~mm})$. (b) two year-old female $(53.9 \mathrm{~mm})$. (c) four year-old female $(56.0 \mathrm{~mm})$. (d) 1 yearold juvenile $(\mathrm{SVL}=37.0 \mathrm{~mm})$. dl: double resting lines, EB: endosteal bone, fc: food canal, MC: marrow cavity, rl: resorption line. Arrows point to lines of arrested growth and resorption lines. Bar $=100 \mu \mathrm{m}$.

range 2-5) in females (Table 1). No statistical difference was observed between males and females in terms of age structure $(\mathrm{U}=115.50$; $P=0.128)$. Although both sexes commonly reached sexual maturity after their second hibernation, some females reached sexual maturity after their third hibernation.

Snout-vent length at metamorphosis $\left(\mathrm{SVL}_{\text {met }}\right)$ was estimated as $26 \mathrm{~mm}(\mathrm{SD}=12.36$; $\mathrm{N}=14$ ), by measuring newly metamorphosed individuals at the end of June from Lake Sülüklü (Fig. 1d). According to the von Bertalanffy equation, the $\mathrm{SVL}_{\max }$ was calculated as $90.22(\mathrm{SE}=31.89)$, $\mathrm{K}$ as $0.30(\mathrm{SE}=0.33)$ and $\mathrm{t}_{\text {met }}$ as 0.03 (SE =0.87) (Fig. 2).

\section{DISCUSSION}

This study revealed that the estimated average age and longevity of $P$. bedriagae from Lake Sülüklü were, respectively, 2.50 and 4 years in males and 2.95 and 5 years in females. The individuals reached sexual maturity after their second hibernation, and the modal age was two years for males and three years for females.

The previous studies reported that the first LAG generally disappeared (fully or partially) after reaching sexual maturity (e.g. Rozenblut \& Ogielska, 2005; KYRIAKOPOULOU-SKLAVOUNOU et al., 2008; 
SOCHA \& OGIELSKA, 2010, GÜl et al., 2011). The first LAG of Lake Sülüklü population was entirely or partially resorbed by the endosteal bone. Besides, double resting lines in some individuals were also detected. The double resting lines in the bone are generally formed as a result of either a short activity period during hibernation (HemelaAr \& van Gelder, 1980), a starvation period, an exposure to cold temperatures during the activity period (SMIRINA et al., 1986) or other environmental factors (SOCHA \& OGIELSKA, 2010).

Table 2 shows some age and growth parameters of other Pelophylax species. In this genus the maximum longevity reported was 12 years in Caucasian populations (namely for $P$. esculentus and P. lessonae) (SHALDYBIN, 1976; AlexandrovsKaya \& Kotova, 1986), while in European populations it was 11 years. Generally, longevity tends to increase in northern or mountain populations and it tends to decrease in southern or lowland populations (SMIRINA, 1994). In Lake

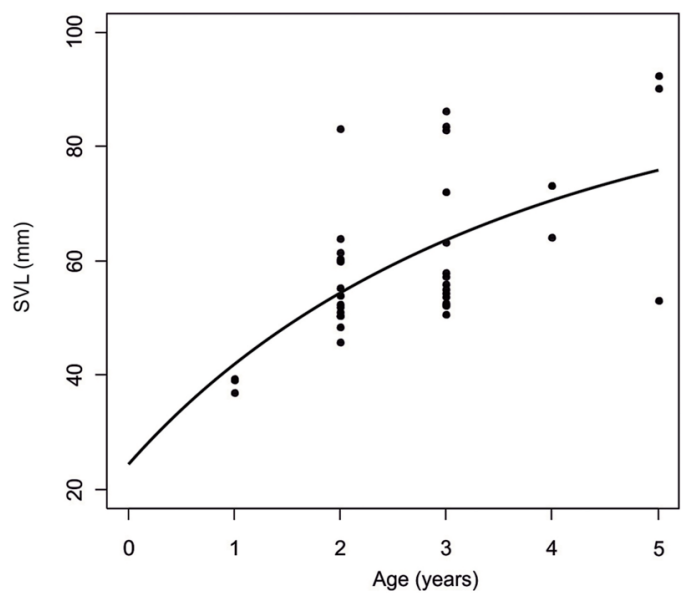

Figure 2: Growth curve of Pelopghylax bedriagae from Lake Sülüklü. SVL $=90.2-(90.2-26.0) \mathrm{e}^{-0.30(\mathrm{t}-0.03)}$.

Sülüklü, the maximum longevity was higher in females than in males, as previously reported by many other researchers working with green frogs (TSIORA \& KYRIAKOPOULOUSKLAVOUNOU, 2002; ERIŞMIŞ, 2005; KYRIAKOPOULOU-SKLAVOUNOU et al., 2008; SOCHA \& OGIELSKA, 2010; GÜL et al., 2011). Nevertheless, we must consider that sampling at Lake Sülüklü was performed on

Table 2: Overall range of ages of adult individuals and values by sexes of mean population age, age at sexual maturity (MAT) and growth rate coefficient (K) of some Pelophylax species studied by skeletochronology. M: males, F: females.

\begin{tabular}{|c|c|c|c|c|c|c|}
\hline Species & Origin & Range $^{2}$ & $\operatorname{Mean}^{2}(\mathrm{M}-\mathrm{F})$ & $\mathrm{MAT}^{\mathrm{a}}(\mathrm{M}-\mathrm{F})$ & $\mathrm{K}(\mathrm{M}-\mathrm{F})$ & Reference \\
\hline P. caralitanus & Anatolia & $2-10$ & & $2-3$ & & ERIŞMIȘ (2005) \\
\hline \multirow[t]{6}{*}{ P. ridibundus } & Russia & $4-11$ & & & & $\begin{array}{l}\text { SHALDYBIN, 1976; ALEXANDROVSKAYA \& } \\
\text { KOTOVA, 1986; SMIRINA, } 1994\end{array}$ \\
\hline & Georgia & $2-7$ & $2.78-4.03$ & 2 & & GOKHELASHVILI \& TARKHNISHIVILI (1994) \\
\hline & Anatolia & $1-7$ & $3.90-3.72$ & $2-4$ & & YILMAZ et al. (2005) \\
\hline & Anatolia & $2-8$ & & 2 & & GüL et al. (2011) \\
\hline & Anatolia & $4-11$ & & $3-4$ & & GüL et al. (2011) \\
\hline & Greece & $1-5$ & $2.96-3.73$ & 1 & & KYrIAKOPOULOU-SKLAVOUNOU et al. (2008) \\
\hline \multirow[t]{2}{*}{ P. esculentus complex } & Romania & $4-10$ & $5.0-6.7$ & 4 & $0.22-0.28$ & COGĂLNICEANU \& MiAUD (2003) \\
\hline & Poland & $2-7$ & 4.1 & $2-3$ & $0.76-0.59$ & SOCHA \& OGIELSKA (2010) \\
\hline P. epeirotica & Greece & $1-5$ & $2.82-3.22$ & 1 & $0.88-0.49$ & TSIORA \& KYRIAKOPOULOU-SKLAVOUNOU (2002) \\
\hline P. bedriagae & Anatolia & $2-5$ & $2.50-2.95$ & 2 & 0.30 & Present study \\
\hline
\end{tabular}


a single day and at the end of the breeding season, and older individuals might have already come back to their refuges, thus causing a bias in estimation of age structure and an underestimation of maximum longevity.

The growth rate estimated in $P$. bedriagae population from Lake Sülüklü (0.30) is lower than that of most European Pelophylax species (0.22-0.88; Table 2), which could be related to habitat quality, environmental conditions, and predator pressure. Lake Sülüklü is surrounded by cherry orchards. The wastes of agricultural pesticides used in orchards are mixed with rainwater or spilled directly to the lake. In addition, the owners of the surrounding orchards use the water of the lake for irrigation. Another element of pressure is predation from the common carp (Cyprinus carpio), which has been repeatedly introduced to the lake. These fishes may reach body sizes up to $40-50 \mathrm{~cm}$.

In conclusion, when the Lake Sülüklü population of $P$. bedriagae is compared with other Caucasian and European Pelophylax populations, the age composition resembles that of the European ones. Furthermore, there are anthropogenic factors that threaten this population. Younger average age of the studied population as well as lower longevity, survival and growth rate in comparison with other Pelophylax populations could be caused by impoverished habitat quality and environmental conditions, as well as by predator pressure.

\section{Acknowledgement}

We thank Derek H. Ogle for your help in using $\mathrm{R}$ version 2.12.2 and Ivelin Mollow for reviewing English style.

\section{REFERENCES}

AleKsandrovskaya, T.O. \& KotOVA, E.L. (1986). Preliminary data on age characteristics of Rana ridibunda Pallas from Armenia. Proceedings of the Zoological Institute of the USSR Academy of Sciences 157: 177-181.

AMPHiBIAWEB (2011). AmphibiaWeb: Information on Amphibian Biology and Conservation. University of California, Berkeley, California, USA. Available at http://www.amphibiaweb.org/. Retrieved on 05/30/2011.

Arntzen, J.W. (2000). A growth curve for the newt Triturus cristatus. Journal of Herpetology 34: 227-232.

Baran, İ.; YilmaZ, İ., Kumlutaş, Y. \& Kete, R. (1992). Türkiye ova kurbağası (Rana ridibunda) stok tespiti (Anura, Ranidae). Turkish Journal of Zoology 16: 289-299.

BeERLi, P. (1995). Rana bedriagae Camerano 1882. Version 20 December 1995, In D.R. Madison \& K.-S. Schulz (eds.) The Tree of Life Web Project. The University of Arizona College of Agriculture and Life Sciences and The University of Arizona Library, Tucson, Arizona, USA. Available at http://tolweb.org/. Retrieved on $05 / 30 / 2011$.

Castanet, J. \& Smirina, E. (1990). Introduction to the skeletochronological method in amphibians and reptiles. Annales des Sciences Naturelles, Zoologie et Biologie Animale, Séries 13 11: 191-196.

Castanet, J.; Francillon-Vieillot, H.; Meunier, J.F. \& DE RicQlés, A. (1993). Bone and individual aging, In B.K. Hall (ed.) Bone, Volume 7: Bone Growth-B. CRC Press, Boca Raton, Florida, USA, pp. 245-283.

Castanet, J.; Meunier, F. \& De RicQlés, A. (1977). L'enregistrement de la croissance cyclique par le tissue osseux chez 
les vertébrés poikilothermes: données comparatives et essai de synthèse. Bulletin Biologique de la France et de la Belgique 111: 183-202.

CoĞalniceanu, D. \& Miaud, C. (2003). Population age structure and growth in four syntopic amphibian species inhabiting a large river floodplain. Canadian Journal of Zoology 81: 1096-1106.

ERIŞMIŞ, U.C. (2005). Göller bölgesi Rana ridibunda (Anura: Ranidae) populasyonlarnda yass - boy, yass - ağrrlik ve boy-ăgrrllk iliskilerinin araşttrlması. Ph.D. dissertation, Ege University, Bornova-Izmir, Turkey.

Frost, D.R. (2011). Amphibian Species of the World 5.5, an Online Reference. American Museum of Natural History, New York, USA. Available at http://research.amnh. org/vz/herpetology/amphibia/. Retrieved on $05 / 30 / 2011$.

GOKHELASHVILI, R.K. \& TARKHNISHVILI D.N. (1994). Age structure of six Georgian anuran populations and its dynamics during two consecutive years (Anura). Herpetozoa 7: 11-18.

Guarino, F.M., Di Già, I. \& Sindaco, R. (2008). Age structure in a declining population of Rana temporaria from northern Italy. Acta Zoologica Academiae Scientiarum Hungaricae 54: 99-112.

GÜL, S.; ÖZDEMIR, N.; ÜZÜM, N.; Olgun, K. \& Kutrup, B. (2011). Body size and age structure of Pelophylax ridibundus populations from two different altitudes in Turkey. Amphibia-Reptilia 32: 287-292.

HeMELAAR, A.S.M. \& VAN GELDER, J.J. (1980). Annual growth rings in phalanges of Bufo bufo (Anura, Amphibia) from the Netherlands and their use for age determination. Netherlands Journal of Zoology 30: 129-135.
HemelaAR, A.S.M. (1985). An improved method to estimate the number of annular rings resorbed in phalanges of Bufo bufo (L.) and its application to populations from different latitudes and altitudes. Amphibia-Reptilia 6: 323-343.

Hemelaar, A. (1988). Age, growth and other population characteristics of Bufo bufo from different latitudes and altitudes. Journal of Herpetology 22: 369-388.

KLeINENBERG, S.E. \& SMirina, E.M. (1969). [A contribution to the method of age determination in amphibians]. Zoologicheskii Zhurnal 48: 1090-1094 (in Russian).

Kyriakopoulou-SKLaVounou, P.; STYLIANOU, P. \& TSIORA, A. (2008). A skeletochronological study of age, growth and longevity in a population of the frog Rana ridibunda from southern Europe. Zoology 111: 30-36.

Miaud, C.; Andreone, F.; Ribéron, A.; De Michelis, S.; Clima, V.; Castanet, J.; FRANCILLON-VIEILLOT, H. \& GUYÉTANT, R. (2001). Variations in age, size at maturity and gestation duration among two neighbouring populations of the Alpine salamander (Salamandra lanzai). Journal of Zoology 254: 251-260.

Papenfuss, T.; Kuzmin, S.; Disi, A.M.M.; Degani, G.; Ugurtas, I.H.; SParReboOM, M.; Anderson, S.; Sadek, R.; HraouiBloquet, S.; Gasith, A.; Elron, E.; GAFNY, S.; LyMBeraKis, P.; BÖHME, W. \& El Din, S.B. (2008). Pelophylax bedriagae, In IUCN (2010) The IUCN Red List of Threatened Species, v. 2010.4. International Union for Nature Conservation and Natural Resources, Gland, Switzerland. Available at http://www.iucnredlist.org/. Retrieved on 05/30/2011. 
R Development Core Team (2011). $R$ : $A$ Language and Environment for Statistical Computing. R Foundation for Statistical Computing, Vienna, Austria. Avaliable at http://www.r-project.org/. Retrieved on 05/30/2011.

Rozenblut, B. \& Ogielska, M. (2005). Development and growth of long bones in European water frogs (Amphibia: Anura: Ranidae), with remarks on age determination. Journal of Morphology 265: 304-317.

Sarasola-Puente, V.; Gosá, A.; Oromí, N.;

Madeira, M.J. \& Lizana, M. (2011). Growth, size and age at maturity of the agile frog (Rana dalmatina) in an Iberian Peninsula population. Zoology 114: 150-154.

SHALDYBIN, S.L. (1976). [Age and sex structure of populations of anurans]. Prirodnye Resursy Volzhsko-Kamskogo Kraya 4: 112117 (in Russian).

SMIRINA, E.M. (1972). [Annual layers in bones of Rana temporaria]. Zoologicheskii Zhurnal 51: 1529-1534 (in Russian).

SMiRINA, E.M. (1994). Age determination and longevity in amphibians. Gerontology 40: 133-146.
Smirina, E.M.; KleVezal, G.A. \& Berger, L. (1986). [Experimental investigation of the annual layer formation in bones of amphibians]. Zoologicheskii Zhurnal 65: 1526-1534 (in Russian).

Socha, M. \& Ogielska, M. (2010). Age structure, size and growth rate of water frogs from central European natural Pelophylax ridibundus-Pelophylax esculentus mixed populations estimated by skeletochronology. Amphibia-Reptilia 31: 239-250.

Tsiora, A. \& KyriakopoulouSklavounou, P. (2002). A skeletochronological study of age and growth in relation to adult size in the water frog Rana epeirotica. Zoology 105: 55-60.

VON BERTALANFFY, L. (1983). A quantitative theory of organic growth (Inquiries on growth law. II). Human Biology 10: 181-213.

Yilmaz, N.; Kutrup, B.; ÇobanoĞLu, Ü. \& ÖZORAN, Y. (2005). Age determination and some growth parameters of a Rana ridibunda population in Turkey. Acta Zoologica Academiae Scientiarum Hungaricae 51: 67-74. 